\title{
PERBAIKAN KUALITAS TEPUNG PUTIH TELUR AYAM RAS DENGAN FERMENTASI MENGGUNAKAN RAGI TEMPE
}

\section{Improving The Quality of White Eggs Powder by Yeast Tempeh Fermentation}

\author{
1Rosa Tri Hertamawati dan ${ }^{\mathbf{1}}$ Abid Muhammad \\ 1Program Studi Manajemen Bisnis Unggas, Jurusan Peternakan, Politeknik Negeri Jember \\ Email: rosa_trihertamawati@polije.ac.id
}

\begin{abstract}
ABSTRAK
Penelitian ini bertujuan untuk mengetahui pengaruh lama waktu fermentasi ragi tempe yang berbeda terhadap kualitas tepung putih telur. Metode penelitian menggunakan rancangan acak lengkap (RAL). Perlakuan lama waktu fermentasi yang digunakan yaitu P0 (tanpa fermentasi), P1 (6 jam), P2 (12 jam), dan P3 (24 jam) dengan 5 ulangan. Parameter yang diamati adalah kadar protein, kadar air, kadar abu, dan warna. Data hasil uji kadar protein, kadar air, kadar abu, dan warna dianalisis dengan analisis variansi dan diuji lanjut dengan uji Duncan Multiple Range Test. Hasil penelitian menunjukkan bahwa lama fermentasi ragi tempe yang berbeda meningkatkan kadar protein, dan menurunkan kadar air, kadar abu, dan skor warna tepung putih telur. Lama fermentasi ragi tempe selama 6 jam dapat memperbaiki kualitas tepung putih telur ayam ras.
\end{abstract}

Kata kunci: Fermentasi, Ragi Tempe, Tepung Putih Telur

\begin{abstract}
This study aims to determine the effect of different fermentation time of tempeh yeast on the quality of egg white flour. The research method used a completely randomized design (CRD). The treatments used for fermentation time were PO (without fermentation), P1 (6 hours), P2 (12 hours), and P3 (24 hours) with 5 replications. The parameters observed were protein content, moisture content, ash content, and color. The data from the test results of protein content, moisture content, ash content, and color were analyzed by analysis of variance and further tested with the Duncan Multiple Range Test. The results showed that different fermentation time for tempeh yeast increased protein content, and decreased moisture content, ash content, and egg white flour color score. Tempe yeast fermentation time for 6 hours can improve the quality of egg white flour.
\end{abstract}

Keywords: Fermentation, Tempeh Yeast, Egg White Flour

\section{PENDAHULUAN}

Tepung putih telur banyak dimanfaatkan diindustri kue serta industri permen. Telur ayam ras mempunyai permasalahan yakni memiliki daya simpan yang pendek sehingga perlu dilakukan pengawetan terhadap telur untuk memperpanjang daya simpannya. Penyimpanan telur dapat menurunkan kualitas telur itu, semakin lama telur disimpan kualitas dan kesegaran telur akan menurun, telur hanya bertahan 10 sampai 14 hari pada suhu ruang dan maksimal selama 25 hari (Fibrianti, 2012).

Salah satu cara yang dilakukan supaya daya simpan telur lebih lama dilakukan pengolahan dengan cara diolah menjadi tepung putih telur. Proses pembuatan tepung putih telur dengan metode pengeringan bertujuan untuk mengurangi dan mencegah kegiatan mikroorganisme sehingga memperpanjang daya simpan, mengurangi ruang penyimpanan, mempermudah penanganan dan 
transportasi (Winarno \& Koswara, 2002). Proses pengeringan tepung putih telur memiliki kelemahan yakni terjadi reaksi maillard, yang merupakan reaksi pencoklatan karena karbohidrat dan protein bereaksi selama proses pengeringan sehingga dapat menyebabkan warna kuning akibat pemanasan. Reaksi maillard tersebut dapat di atasi dengan proses fermentasi yang dapat merombak karbohidrat sehingga warna yang dihasilkan lebih putih (Winarno \& Sutrisno, 2004).

Tujuan fermentasi telur adalah proses penghilangan glukosa yang terdapat pada telur dengan menanbahkan ragi, proses fermentasi menyebabkan terjadinya perubahan sifat fisik serta fungsional karena adanya pemecahan glukosa yang terjadi di dalam telur khususnya putih telur sehingga bisa mencegah reaksi maillard. Ragi banyak di gunakan untuk fermentasi karena aplikasinya mudah, fermentasi yang akan digunakan adalah dengan ragi tempe, fermentasi dengan ragi tempe dapat memberikan efek positif seperti terjadinya penurunan karbohidrat, asam lemak meningkat, dan adanya aktivitas enzim protease yang dapat menguraikan protein (Karmini et al., 1996). Lama waktu fermentasi dapat mempengaruhi hasil dari pembuatan tepung putih telur (Nusa et al., 2017).

\section{METODE}

\section{Bahan dan Alat}

Bahan yang digunakan pada penelitian ini adalah putih telur ayam ras berumur satu hari sebanyak $100 \mathrm{~g}$ di setiap ulangannya, ragi tempe, minyak nabati. Peralatan yang digunakan pada penelitian ini adalah timbangan digital analitik, baskom, sendok, oven, loyang, kertas label, plastik kemasan, gelas ukur, saringan pemisah kuning dan putih telur, kuas, beaker glass, toples, dan sumpit kayu. Metode yang digunakan adalah metode eksperimental. Penelitian akan dilakukan dengan melakukan pembuatan tepung putih telur yang difermentasi dengan menggunakan ragi tempe sebesar 0,4\% dari $100 \mathrm{~g}$ putih telur (Nusa et al., 2017).

\section{Prosedur}

Prosedur pembuatan tepung putih telur dimulai dengan persiapan telur. Telur yang digunakan adalah telur ayam ras diperoleh dari peternakan ada di politeknik negeri jember berumur satu hari, telur yang sudah didapat lalu dibersihkan dari kotoran yang menempel pada cangkang telur, kemudian pemisahan telur yang kotor dengan tidak kotor serta retak dan tidak retak. Pemisahan putih telur dengan kuning telur dengan cara menggunakan alat penyaring khusus pemisah putih telur dan kuning telur, lalu putih telur ditimbang seberat $100 \mathrm{~g}$ kemudian ditempatkan pada toples. Fermentasi putih telur ragi tempe ditambahkan sebanyak 0,4\% ke dalam putih telur, lalu diaduk hingga merata dan didiamkan selama 6, 12, dan 24 jam pada suhu ruang (26 sampai $30^{\circ} \mathrm{C}$ ). Pengeringan putih telur dapat dilakukan setelah putih telur sudah difermentasi kemudian dimasukkan kedalam loyang yang sudah dioles dengan minyak, putih telur kemudian dikeringkan dalam oven dengan suhu $58^{\circ} \mathrm{C}$ selama 24 jam.

Penggilingan dilakukan setelah putih telur dikeringkan kemudian dihaluskan hingga berbentuk tepung, lalu tepung putih telur dilakukan pengemasan dengan plastik kemasan dan dilakukan analisis kimia. Parameter pengamatan yang akan dilakukan dalam penelitian ini adalah analisa kimia yang meliputi kadar air, kadar abu, kadar protein, dan warna.

\section{Analisis Data}

Penelitian ini menggunakan rancangan acak lengkap (RAL) dengan 4 perlakuan dan 5 ulangan setiap ulagan terdiri dari 100 g putih telur. Formulasi pembuatan tepung putih telur dengan difermentasi dan tidak difermentasi. Perlakuan lama fermentasi yaitu P0 (tanpa fermentasi), P1 (6 jam), P2 (12 jam), dan P3 (24 jam). Data hasil uji kadar protein, kadar air, kadar abu, dan warna dianalisis dengan analisis variansi dan diuji lanjut dengan uji Duncan Multiple Range Test. 


\section{HASIL DAN PEMBAHASAN}

\section{Kadar Protein}

Rata-rata kadar protein tepung putih telur yang difermentasi dengan ragi tempe dapat dilihat dalam Tabel 1.

Tabel 1. Rata-rata Kadar Protein Tepung Putih Telur yang Difermentasi Dengan Ragi Tempe

\begin{tabular}{ccccccc}
\hline \multirow{2}{*}{ Perlakuan } & \multicolumn{5}{c}{ Ulangan } & \multirow{2}{*}{ Rata-rata } \\
\cline { 2 - 6 } & 1 & 2 & 3 & 4 & 5 & \\
\hline P0 & 26,12 & 26,08 & 26,01 & 26,02 & 26,18 & $26,08^{\mathrm{c}}$ \\
P1 & 27,84 & 27,75 & 27,77 & 27,78 & 27,71 & $27,77^{\mathrm{b}}$ \\
P2 & 27,90 & 27,80 & 27,76 & 27,80 & 27,84 & $27,82^{\mathrm{ab}}$ \\
P3 & 27,96 & 27,90 & 27,78 & 27,90 & 27,96 & $27,90^{\mathrm{a}}$ \\
\hline
\end{tabular}

abc Superskrip yang berbeda pada kolom yang asma menunjukan perbedaan yang nyata $(\mathrm{P}<0,05)$

Hasil penelitian menunjukan bahwa lama fermentasi ragi tempe yang berbeda berpengaruh nyata $(\mathrm{P}<0,05)$ terhadap kadar protein tepung putih telur. Kadar protein tepung putih telur terbaik adalah 27,90\% dengan lama fermentasi 24 jam (P3), terdapat peningkatan yang signifikan setelah dilakukan uji lanjut. Peningkatan pada perlakuan P1 sebesar 1,69\% dari P0, P2 sebesar 1,74\% dari P0, dan P3 sebesar 1,82\% dari P0. Putih telur yang digunakan $100 \mathrm{~g}$ selama proses fermentasi berat putih menurun menjadi kurang lebih 5 hingga $10 \mathrm{~g}$ dan tinggi ketebalan waktu pengovenan kurang lebih 0,25 mm. Lama fermentasi akan menurunkan nilai pH (Nusa et al., 2017). Karena tingginya asam dapat menyebabkan penurunan nilah pH (Stadelman \& Cotterill, 1995).

Semakin lama fermentasi maka kadar protein yang dihasilkan akan meningkat (Nusa et al., 2017). Peningkatan ini dikarenakan lama waktu fermentasi akan memberikan ragi tempe kesempatan untuk menghasilkan asam amino serta juga merombak makromolekul menjadi senyawa sederhana kemudian menghasilkan gas dan udara yang menguap sehingga menghasilkan peningkatan pada protein (Winarno \& Sutrisno, 2004). Terjadinya peningkatan kadar protein disetiap perlakuan mempunyai hubungan negatif dengan kadar air, semakin rendahnya kadar air mengakibatkan meningkatnya kadar protein, hal ini dikarenakan tidak terjadinya perombakan protein akibat aktivitas ragi tempe disaat kadar air rendah (Dwidjoseputro, 2005).

\section{Kadar Air} Tabel 2.

Rata-rata kadar air tepung putih telur yang difermentasi dengan ragi tempe dapat dilihat dalam

Tabel 2. Rata-rata Kadar Air Tepung Putih Telur yang Difermentasi Dengan Ragi Tempe

\begin{tabular}{ccccccc}
\hline \multirow{2}{*}{ Perlakuan } & \multicolumn{5}{c}{ Ulangan } & \multirow{2}{*}{ Rata-rata } \\
\cline { 2 - 6 } & 1 & 2 & 3 & 4 & 5 & \\
\hline P0 & 6,11 & 6,04 & 6,11 & 6,07 & 6,13 & $6,09 \mathrm{c}$ \\
P1 & 5,92 & 5,90 & 5,87 & 5,90 & 5,91 & $5,90^{\mathrm{b}}$ \\
P2 & 5,90 & 5,87 & 5,91 & 5,90 & 5,89 & $5,89^{\mathrm{ab}}$ \\
P3 & 5,87 & 5,83 & 5,87 & 5,85 & 5,90 & $5,86^{\mathrm{a}}$ \\
\hline
\end{tabular}

ab Superskrip yang berbeda pada kolom yang asma menunjukan perbedaan yang nyata $(\mathrm{P}<0,05)$

Hasil penelitian menunjukan bahwa lama fermentasi dengan ragi tempe memberikan pengaruh yang nyata $(\mathrm{P}<0,05)$ terhadap kadar air tepung putih telur. Kadar air tepung putih telur terbaik adalah 5,86\% dengan lama fermentasi 24 jam (P3), terdapat penurunan yang signifikan setelah dilakukan uji lanjut. Penurunan pada perlakuan P1 sebesar 0,19\% dari P0, P2 sebesar 0,20\% dari P0, dan P3 sebesar 0,23\% dari P0. Semakin lama fermentasi kada air yang dihasilkan semakin rendah (Nusa et al., 2017). Penurunan ini disebabkan oleh semakin lama fermentasi aktivitas pada 
ragi tempe semakin menurun karena substratnya terbatas menjadikan kadar air yang dihasilkan jadi semakin sedikit, proses fermentasi adanya perombakan antara glukosa menjadi karbondioksida dan air yang membuat kadar air menurun dan dapat menjadi bahan kering (Fardiaz, 1992). Kadar air yang rendah ini dapat meningkatkan daya simpan tanpa mengurangi nilai gizi (Winarno \& Koswara, 2002).

\section{Kadar Abu}

Rata-rata kadar abu tepung putih telur yang difermentasi dengan ragi tempe dapat dilihat dalam Tabel 3.

Tabel 3. Rata-rata Kadar Abu Tepung Putih Telur yang Difermentasi dengan Ragi Tempe

\begin{tabular}{ccccccc}
\hline \multirow{2}{*}{ Perlakuan } & \multicolumn{7}{c}{ Ulangan } & \multirow{2}{*}{ Rata-rata } \\
\cline { 2 - 6 } & 1 & 2 & 3 & 4 & 5 & \\
\hline P0 & 1,71 & 1,70 & 1,68 & 1,75 & 1,70 & $1,71^{\mathrm{d}}$ \\
P1 & 1,57 & 1,58 & 1,55 & 1,54 & 1,58 & $1,56^{\mathrm{c}}$ \\
P2 & 1,50 & 1,52 & 1,54 & 1,52 & 1,51 & $1,52^{\mathrm{b}}$ \\
P3 & 1,47 & 1,48 & 1,47 & 1,51 & 1,49 & $1,48^{\mathrm{a}}$ \\
\hline
\end{tabular}

abcd Superskrip yang berbeda pada kolom yang asma menunjukan perbedaan yang nyata $(\mathrm{P}<0,05)$

Hasil penelitian menunjukan lama fermentasi dengan ragi tempe memberikan pengaruh yang nyata $(\mathrm{P}<0,05)$ terhadap kadar abu tepung putih telur. Kadar abu tepung putih telur terbaik adalah 1,48\% dengan lama fermentasi 24 jam (P3), terdapat penurunan yang signifikan setelah dilakukan uji lanjut. Penurunan pada perlakuan P1 sebesar 0,15\% dari P0, P2 sebesar 0,19\% dari P0, dan P3 sebesar 0,23\% dari P0.

Kadar abu merupakan mineral yang secara umum tidak akan terjadi perubahan selama proses penyimpanan, namun dengan naiknya kadar air menyebabkan terjadinya kenaikan berat basah yang membuat kadar abu meningkat (Mudambi \& Rajagopal, 1980). Semakin lama fermentasi nilai kadar abu semakin menurun di setiap perlakuannya, ini disebabkan oleh semakin lama fermentasi aktivitas pada ragi tempe semakin menurun karena substratnya terbatas. Perubahan nilai penurunan di setiap perlakuannya berawal dengan nilai 1,71\% menjadi 1,48\%. Standart kadar abu dalam SNI (1996) syarat mutu tepung putih telur adalah tidak lebih dari 5\%. Perlakuan P3 dengan nilai kadar abu terendah bisa dikatakan perlakuan yang terbaik dari perlakuan lainnya.

\section{Warna}

Rata-rata nilai warna tepung putih telur yang difermentasi dengan ragi tempe dapat dilihat dalam Tabel 4.

Tabel 4. Rata-rata Warna Tepung Putih Telur yang Difermentasi dengan Ragi Tempe

\begin{tabular}{cccccccc}
\hline \multirow{2}{*}{ Perlakuan } & \multicolumn{9}{c}{ Ulangan } & \multirow{2}{*}{ Rata-rata } \\
\cline { 2 - 6 } & 1 & 2 & 3 & 4 & 5 & \\
\hline P0 & 69 & 61 & 71 & 62 & 61 & $2,59 \mathrm{~d}$ \\
P1 & 32 & 32 & 34 & 32 & 32 & $1,30^{\mathrm{a}}$ \\
P2 & 52 & 40 & 46 & 51 & 53 & $1,94^{\mathrm{c}}$ \\
P3 & 39 & 36 & 40 & 31 & 35 & $1,45^{\mathrm{b}}$ \\
\hline
\end{tabular}

abcd Superskrip yang berbeda pada kolom yang asma menunjukan perbedaan yang nyata $(\mathrm{P}<0,05)$

Hasil penelitian menunjukan bahwa lama fermentasi dengan ragi tempe memberikan pengaruh yang nyata $(\mathrm{P}<0,05)$ terhadap nilai warna tepung putih telur. Nilai warna tepung putih telur terbaik adalah 1,30 (warna putih) dengan lama fermentasi 6 jam (P1), terdapat perbedaan yang 
signifikan setelah dilakukan uji lanjut. Tabel 4 menunjukan bahwa nilai terkecil dari parameter warna adalah perlakuan P1 lama fermentasi 6 jam yaitu 1,30 (warna putih) ini menunjukan bahwa warna pada perlakuan P1 dapat dinyatakan menjadi warna paling baik. Setiap perlakuan mengalami perubahan warna hal ini menunjukakan adanya perombakan glukosa sehingga dapat mencegah reaksi Maillard (Nusa et al., 2017). Lama fermentasi menyebabkan perombakan glukosa sehingga warna yang dihasilkan putih (Winarno \& Sutrisno, 2004).

\section{KESIMPULAN}

Kesimpulan yang diperoleh dari penelitian ini adalah terdapat peningkatan kadar protein hingga 27,90\% pada perlakuan P3, nilai kadar air menurun hingga 5,86\% pada perlakuan P3, nilai kadar abu menurun hingga 1,48\% pada perlakuan P3, dan nilai warna terbaik 1,30 (warna putih) pada perlakuan P1.

\section{DAFTAR PUSTAKA}

Dwidjoseputro, D. (2005). Dasar -Dasar Mikrobiologi. Jakarta: Djambatan.

Fardiaz, S. (1992). Mikrobiologi Pangan. Jakarta: PT Gramedia Pustaka Utama.

Fibrianti, S. (2012). Kualitas telur ayam konsumsi yang dibersihkan dan tanpa dibersihkan selama penyimpanan suhu kamar. Indonesia Medicus Veterinus, 1, 408-16.

Karmini, M., Sutopo, D. \& Hermana. (1996). Aktivitas enzim hidrolitik kapang Rhizopus Sp. pada proses fermentasi tempe. Jurnal Penelitian Gizi dan Makanan, 19(4), 93-102.

Legowo, A. M. \& Hayakawa, S. (2012). Functionalities of Animal Food Protein. Semarang: Badan Penerbit Universitas Diponegoro.

Li-Chan, E. C. Y., Powrie, W. D. \& Nakai, S. (1995). The chemistry of eggs and egg products. In: Egg Science and Technology, Eds. W. J. Stadelman and O.J. Cotterill. 4th ed. New York.: The Haworth Press Inc., pp. 105-176.

Mudambi, S. \& Rajagopal, M. (1980). Fundamental of Food and Nutrition. New Delhi: Wiley Eastern Limited.

Nusa, I., Budi, S. \& Ali, M. R. (2017). Addition of tempe and old fermentation to the quality of. Albumin flour egg. Agrium: Jurnal Ilmu Pertanian, 20(3), 211-21.

Stadelman, W. J \& Cotterill, O. J. (1995). Egg Science and Technology. 4th ed. New York: Ed. Food Products Press.

Winarno, F. G. \& Sutrisno. K. (2004). Telur: Komposisi, Penanganan dan Pengolahannya. Bogor: MBrio Press.

Winarno, F. G. \& Koswara, S. (2002). Telur, Penanganan Dan Pengolahannya. Bogor: M-brio Press. 